\title{
THE VOICE OF INDONESIAN MIGRANT WORKERS ABROAD: HOW IS THE LEGAL ASSISTANCE FOR THEM?
}

\author{
Fatimatul Uluwiyah* \\ The Focal Point on Migrant Protection, Jakarta, Indonesia \\ *Email: fatimatul_uluwiyah@gmail.com
}

\begin{abstract}
Indonesian Migrant Workers who work abroad often receive treatment that is not in accordance with what was agreed upon, during the validity period of the employment contract, Indonesian Migrant Workers or abbreviated as TKI do not get their rights as workers, and often receive bad treatment such as persecution in the form of physical. In its development, several existing cases have been found, such as several female workers working in Saudi Arabia who have experienced bad treatment, either in the form of sexual abuse or harassment by their employers, besides that in the country, there are many TKI and TKW who receive bad treatment and violations of their rights. The problems raised in this research consist on what are the requirements and procedures for submitting and providing legal assistance for Indonesian migrant workers abroad, and how is the Government's response in providing legal assistance to migrant workers.
\end{abstract}

Keywords: Indonesian Migrant Worker; Legal Protection; Legal Assistance; TKI

The Indonesian Journal of International Clinical Legal Education DOI: https://doi.org/10.15294/ijicle.v3i3.48262

Submitted: Feb 22, 2021 Revised: April 25, 2021 Accepted: August 9, 2021 Available online at https://journal.unnes.ac.id/sju/index.php/iccle (C) 2021 Authors. This work is licensed under a Creative Commons AttributionShareAlike 4.0 International License (CC BY-SA 4.0). All writings published in this journal are personal views of the authors and do not represent the views of this journal and the author's affiliated institutions. 
Fatimatul Uluwiyah

\section{INTRODUCTION}

Indonesian Migrant Workers who work abroad often receive treatment that is not in accordance with what was agreed upon, during the validity period of the employment contract, Indonesian Migrant Workers or abbreviated as TKI do not get their rights as workers, and often receive bad treatment such as persecution in the form of physical. In its development, several existing cases have been found, such as several female workers working in Saudi Arabia who have experienced bad treatment, either in the form of sexual abuse or harassment by their employers, besides that in the country there are many TKI and TKW who receive bad treatment and violations of their rights. his rights. As happened in the case of Zini Misrin who received the death penalty from Saudi Arabia who was accused of murdering her employer in 2004,

In Law No. 16 of 2011 concerning Legal Aid states that the state guarantees the constitutional rights of everyone to obtain recognition, protection, and fair legal certainty as well as equal treatment before the law as a means of protecting human rights and the state is responsible for providing legal aid for the poor or underprivileged who deserve legal aid and access to justice as a manifestation of access to justice so that equitable social change can be implemented.

Legal assistance is also given to Indonesian citizens who work abroad, this is also regulated in Law Number 18 of 2017 concerning the Protection of Indonesian Migrant Workers which states that the state guarantees rights, opportunities, and provides protection for every citizen without discrimination to get a job. and decent income at home and abroad and for that migrant workers must be protected from human trafficking, slavery and forced labor, victims of violence, arbitrariness, crimes against human dignity, and other treatment that violates human rights.

In Article 4 paragraph (2) of the Law on Legal Aid, its scope is very narrow because it relates to civil and criminal matters, whereas problems in society also include manpower, agrarian and other matters. ${ }^{1}$ As experienced by overseas migrant workers who have problems with several cases that are not only civil and criminal cases, but also employment problems, such as unpaid overtime, not being given holidays, and other benefits.

Based on the description above, this paper will discuss legal aid for Indonesian workers abroad on how to access legal aid, the

1 Antonius Sidik Maryono, Critical Study of Law Number 16 of 2011 concerning Legal Aid, National Seminar on Optimizing Legal Aid in Indonesia The Struggle for the Poor, (Yogyakarta: Atmajaya University, 2012), p. 6. 
implementation of legal aid, and the forms of problems faced by Indonesian workers abroad based on the Aid Act. Laws, international conventions that have been ratified, as well as the Act on the protection of Indonesian Migrant Workers. Based on the description above, the formulation of the problem in this research are: (1) What are the requirements and procedures for submitting and providing legal assistance for Indonesian migrant workers abroad? And (2) How is the Government's response in providing legal assistance to migrant workers?

This research, the author uses juridical, normative and descriptive methods, namely using methods by analyzing based on applicable regulations and some existing literature such as books and other scientific works.The method used in this research is normative juridical research. The research approach used is a statutory and case research approach. The statutory approach is used to find out the overall applicable law. The case approach is used to study legal norms or rules carried out in legal practice, ${ }^{2}$ relating to Indonesian Workers and Institutions participating in the provision of legal aid and legal protection. By reviewing several articles in the legislation, as well as based on literature in journals, and actual news.

\section{TERMS AND PROCEDURES FOR APPLICATION AND PROVISION OF LEGAL AID FOR INDONESIAN MIGRANT WORKERS ABROAD}

In the Preamble to the 1945 Constitution, it is stated that every citizen has the right to a decent life, and the country protects the entire nation and the homeland of Indonesia. The fulfillment and protection of the basic rights of workers as well as increasing worker participation as mandated in Article 27 paragraph (2) of the 1945 Constitution is one of the efforts to create a people's economy. ${ }^{3}$ Due to the inability of the Government to fulfill job vacancies for Indonesian workers, this migration of Indonesian workers is an effort to equalize the economy, and in this case the Government has the same responsibility for meeting the economic needs of Migrant Workers Abroad.

2 Marnesia, Tiara Puti Marnesia, The Role of the National Agency for the Placement and Protection of Indonesian Migrant Workers (BNP2TKI) Against Migrant Workers Who Violate the Terms of Work Agreements in Law Number 18 of 2017, (Jakarta: Universitas Pembangunan Nasional Veterans Jakarta, 2019), p.12 .

3 Revrisond Bawir, People's Economy: People's Economy and Cooperatives as Supporters of the National Economy, Journal of Social Sciences and Humanities, Vol. 2 No. 2, Bali : Ganesha University of Education Research Institute, November 2006, p.34. 


\section{Fatimatul Uluwiyah}

Article 7 of Law Number 18 of 2017 concerning the Protection of Indonesian Migrant Workers states that protection for TKI includes 3 things, namely protection before work, protection during work, and protection after work. In Article 21, protection during work includes facilitation of the fulfillment of the rights of Indonesian migrant workers, facilities for resolving employment cases, providing consular services, mentoring, mediation, advocacy, and providing legal assistance in the form of facilitation of advocate services by the Central Government and/or Representatives of the Republic of Indonesia and guardianship. in accordance with local state law. ${ }^{4}$

Cases of abuse against Indonesian migrant workers abroad are not only occasional, but often occur, and these cases are always found in every destination country, so that many Indonesian migrant workers' rights are violated and get capital punishment abroad. Legal assistance provided by the government is often not in accordance with what is expected, there are several factors in this case as well as irregularities in the judiciary of migrant workers abroad that cannot reflect justice. However, there are also many abuses and abuses from abroad against Indonesian migrant workers who do not receive legal assistance from the Government, due to several reasons, the most important of which is financial reasons, namely the limited budget provided by the Government to handle cases that occur,

The legal assistance that should be obtained by Indonesian Migrant Workers can guarantee human rights in accordance with the International Convention on Human Rights, as well as guarantee the enforcement of justice and legal certainty that creates prosperity for migrant workers. What should be done by the Minister of Foreign Affairs to provide access to justice and guarantee the rights of Indonesian migrant workers who are abroad is considered less effective. And many Indonesian workers abroad do not have access to proper legal assistance from the Government.

The problems faced by Indonesian Migrant Workers both in the pre-placement phase, during the placement period to post-placement from time to time need to be improved because they are very broad and require the coordination of many parties, both the Government, PPTKIS, and organizations that help voice the rights of ordinary Indonesian Migrant Workers. referred to as the Indonesian Migrant Workers Union and the Indonesian Migrant Workers themselves. The coordination that is intended primarily is in protecting the rights of problematic Indonesian Migrant Workers. ${ }^{5}$

4 Article 21 of Law Number 18 of 2017 concerning the Protection of Indonesian Migrant Workers

5 Sumardiani, Fenny, The role of Indonesian migrant labor unions in protecting the rights of Indonesian workers abroad, Pandecta: Research Law Journal vol. 9. No. 2, 2014, pp. 257-272. 
The terms and procedures for applying for legal aid have been regulated in Law Number 16 of 2011 concerning Legal Aid contained in Article 14 which states the requirements for obtaining legal aid from legal aid providers, including:

a. submit a written application which contains at least the identity of the applicant and a brief description of the subject matter for which Legal Aid is requested. If the applicant cannot write, it can be submitted orally.

b. submit documents relating to cases that have been experienced or are in progress.

c. attach a certificate of incapacity at the applicant's place of residence, in this case Indonesian migrant workers may request the Minister

Then after that the applicant gives the legal aid provider, then waits for a response from the legal aid provider whether it is accepted or rejected, at least the answer is given within 3 days from being submitted, if the legal aid provider refuses, it must be accompanied by clear reasons in accordance with the provisions of the law. -Law on Legal Aid the reasons must be submitted. ${ }^{6}$

Regarding the funding for the provision of legal aid, it is charged to the State Revenue and Expenditure Budget originating from grants or donations and non-binding funding sources. In this case, the Government is obliged to allocate funding regarding the provision of legal aid from the State Budget and Revenue in accordance with the Law on Legal Aid, which is then allocated to the ministry that administers government affairs in the field of law and human rights or now known as the Ministry of Law and Human Rights, but the application for assistance Law for Indonesian migrant workers is regulated separately in Law Number 39 of 2004 which is further regulated in Government Regulation Number 3 of 2013 concerning Protection of Overseas Workers.

In its development, the Law does not accommodate and function properly, because Article 80 states that the government is only responsible for providing legal assistance in the form of guidance and supervision, consular assistance and protection, providing legal assistance, assistance, fulfillment of rights and so on to migrant workers. who have started working in the destination country, it is being stated in Article 1 that it is stated that the definition of Indonesian Migrant Worker is a worker, both prospective and already working who must still be protected, so it is not only migrant workers who have executed a work contract who are protected, but also prospective foreign workers must also receive legal protection and assistance.Because this Law is considered insufficient to accommodate the interests of Migrant Workers who are abroad, there have been various pressures by activists and Legal Aid Institutions to immediately revise it.

6 Article 14 of Law Number 16 of 2011 concerning Legal Aid 


\section{Fatimatul Uluwiyah}

The issue of migrant workers (TKI Overseas) and child labor is very important to be part of the National Access to Justice Strategy document, because even though the government has made various efforts to fulfill their rights, these rights are not necessarily fulfilled properly. Becoming an Overseas TKI is a difficult choice for the workforce themselves because working in another country requires more abilities and skills, while they are generally armed with very minimal skills and expertise, as a result, big risks are unavoidable. ${ }^{7}$

The regulation on dispute resolution of legal issues in the Legal Aid Provisions in Law No. 39 of 2004 classifies legal aid by region, this is regulated in the Dispute Resolution Chapter, namely:

a. Domestically: when a migrant worker has problems with the PPPILN (Implementing the Placement of Indonesian Workers Abroad) while still in the territory of the State of Indonesia, then it is attempted through deliberation and if it does not work, the BNPPILN will provide legal assistance and advocacy (Article 97 paragraphs 1 and 2);

b. Overseas: when a migrant worker has a problem with the user, it is attempted through deliberation and if it is not successful, legal assistance and advocacy will be provided from the Representatives of the Republic of Indonesia and BNPPILN in the receiving country (Article 98 paragraphs 1 and 2);

When compared to PP No. 3 of 2013 concerning the Protection of Indonesian Migrant Workers Abroad, the concept of legal aid in this regulation is very far from the concept of protection. In Article 17 of PP No. 3 of 2013 the concept of legal aid initiated by the DPR only includes legal aid and advocacy which narrows the concept of providing legal aid in the previous law (before it was revised). ${ }^{8}$

Thus, the Draft Law Number 18 of 2017 concerning the Protection of Indonesian Migrant Workers emerged, which was ratified in November. In this Law, the protection of Indonesian migrant workers includes all efforts which are for the benefit of both prospective migrant workers and Indonesian migrant workers and their families which include their wives, husbands, children, parents and family relationships due to legal decisions or decisions in Indonesia or together abroad. The state is with migrant workers in realizing the guaranteed fulfillment of the rights of migrant workers in economic, legal and social aspects.

The protection regulated in Law Number 18 of 2017 concerning the Protection of Indonesian Migrant Workers includes 3 stages, namely: 1. Before work, 2. During work, 3. After work. The requirements for

7 Arpangi Arpangi, Legal Protection Against Indonesian Migrant Workers Abroad, Journal of Legal Reform 3.1 ,2016, pp.149-156.

8 Eny Rofiatul Ngazizah, Encouraging the Guarantee of the Right to Legal Aid for Migrant Workers in the Revision of Law Number 39 Year 2004 concerning the Placement and Protection of Indonesian Migrant Workers Abroad. 
obtaining legal assistance from the government for Indonesian migrant workers abroad are regulated in Article 5, namely the criteria for migrant workers, including:

1. At least 18 years old

2. Have competence

3. Physically and mentally healthy

4. Registered and have a social security membership number

5. Have complete required documents ${ }^{9}$

Being registered and having a social security membership number is very important for the protection of Indonesian Migrant Workers Abroad as well as BPJS TK, because of the many risks that will be borne by Migrant Workers abroad that cannot be predicted beforehand, such as guarantees in the event of an accident. accidents abroad, this BPJS will cover the risks arising from accidents at work, both when going to work and in the course of work.

In addition, there are also guarantees for deaths that occur in Indonesian workers, as in Malaysia, cases have been found for female workers who work in oil palm fields in a company, where at work she fell on a pole to pick palm fruit, until finally she died. and brought back to Indonesia. In this case, social security such as BPJS is very useful for victims who have accidents which will be given to their heirs.

In the Regulation of the Minister of Manpower Number 7 of 2017 concerning the Social Security Program for Indonesian Workers, it also regulates the social security that must be owned by TKI, in this regulation stipulates that every TKI and prospective TKI are required to have and register themselves in social security participation. The benefits of the existence of BPJS TK as stated in Article 14 of the Manpower Regulation Number 7 of 2017 are in the form of medical personnel services provided according to the needs of migrant workers which include: 1. basic and supporting examinations, 2. first and advanced level care, 3. inpatient care, 4. intensive care, 5. diagnostic support, 6. treatment, 7. special services, 8. medical devices and implants, 9. doctor/medical services, 10 . surgery, 11. blood transfusions, 12 . medical rehabilitation. ${ }^{10}$

If the worker works in an environment close to health services that have not collaborated with BPJS, they will be rushed to the nearest medical service with the fixed costs borne by BPJS in accordance with applicable laws and regulations. In addition, if there is an accident that results in a migrant worker dying or being disabled, he will receive compensation in the form of money, and among other things, scholarship fees for his heirs.

9 Article 5 of Law Number 18 of 2017 concerning the Protection of Indonesian Migrant Workers

10 Article 14 Regulation of the Minister of Manpower Number 7 of 2017 concerning the Social Security Program for Indonesian Migrant Workers 


\section{Fatimatul Uluwiyah}

TKI who work and stay abroad often occur discriminatory actions against their employers, as a result of acts of discrimination there are forms of treatment from TKI by defending and causing the employer to die. UU no. 39/2014 concerning the Placement and Protection of Indonesian Migrant Workers Abroad was deemed inadequate. 3/2013 concerning the Protection of Indonesian Migrant Workers Abroad divides legal protection into 3 stages/periods: pre-placement period, placement period and post-placement period.

The International Convention on the Protection of the Rights of All Migrant Workers and Members of Their Families was only ratified in 2010 and included in Law no. 6/2012. ${ }^{11}$ In addition to accident and death insurance, there is also old-age insurance or commonly known as JHT, which JHT will be given to Indonesian migrant workers who have been laid off, terminated their employment contract, dies, permanent total disability becomes a foreign citizen, then the provision of benefits This old age will be adjusted to the accumulated contributions that have been paid to BPJS.

Then in the criteria for migrant workers number 5 is to complete the required complete documents, this includes the completeness and administrative requirements before the departure of Indonesian migrant workers abroad. One of them is the completeness and validity of placement documents, in which prospective Indonesian migrant workers are required to have administrative documents which include:

1. Certificate of marital status for prospective workers who have married by attaching a photocopy of a copy of the marriage book from the Office of Religious Affairs.

2. Certificate of husband or wife permission, permission from parents, or if there is no permission from someone who is still a relative known to the village head or lurah, usually for these prospective migrant workers, the management of this permit has been handled by the tekong or distributors workers abroad.

3. Work competency certificates, usually prospective Indonesian migrant workers who will go abroad whose language and work conditions are a little more complicated, such as in companies and so on, previously these prospective workers took part in on-the-job training in job training centers or studied foreign languages, so they have received a certificate or a valid permit.

4. Health certificate based on the results of a health and psychological examination from a hospital, as well as a medical check-up.

5. Passports issued by the local immigration office, in every district and city there must be one immigration office, prospective workers can carry out management there according to the applicable rules.

11 Atika Fauziati, Legal Protection for Indonesian Migrant Workers Sentenced to Death Abroad in Indonesian Legislation, Collection of Law Faculty Student Journals, 2015, p.1. 
6. Work visas, which are limited to a certain time, this visa will increase state financial income and be included in the state budget, which is then managed by the government, this foreign exchange contributes about 10 percent to the state budget so that Indonesian migrant workers are often known as foreign exchange heroes.

7. Indonesian Migrant Worker Placement Agreements and Employment Agreements. For example, prospective migrant workers who will work in South Korea, generally work there in companies or factories, so they have a limited time work agreement or contract.

Furthermore, the migrant workers can obtain the determination of the conditions and conditions of work.

In Article 17 of Government Regulation Number 3 of 2013 concerning the Protection of Indonesian Migrant Workers Abroad, it is stated that the protection of the period of placement of Indonesian Migrant Workers abroad includes: guidance and supervision, consular assistance and protection, provision of legal assistance, defense of the fulfillment of the rights of Indonesian Migrant Workers. , protection and other assistance in accordance with the provisions of laws and regulations as well as international law and practice, and diplomatic efforts. ${ }^{12}$

TKI are given guidance and advocacy and receive facilities for resolving disputes or disputes between Indonesian Migrant Workers abroad and users or implementers of the placement of Indonesian Migrant Workers, this is a form of guidance and supervision mandated in government regulations. For consular assistance and protection itself, it only covers the management of TKI who experience illness, accident and death, as well as access to communication between state representatives and TKI and access to information to TKI receiving countries if there are TKIs who have legal problems.

For the provision of legal aid itself in Article 20 it is stated that the legal aid in question includes:

1. giving mediation

2. advocacy

3. Assistance to TKI who face legal problems

4. Handling the problem of TKI who experience acts of physical violence and sexual harassment.

5. provision of advocates/ lawyers

The provision of mediation is basically the provision of negotiations that include expert mediators who have been provided by the National Agency for the Placement and Protection of Indonesian Migrant Workers or BPN2TKI and the Government who provide guarantees in effective negotiation methods and can assist the parties in disputes experienced by the workers. Indonesian migrants by

12 Article 17 Government Regulation Number 3 of 2013 concerning the Protection of Indonesian Migrant Workers Abroad 


\section{Fatimatul Uluwiyah}

coordinating activities, and to be more effective in negotiations. Where the mediator is a mediator recruited by the guarantee agency responsible for the rights of Indonesian Migrant Workers. ${ }^{13}$ The stages of dispute resolution experienced by TKI/Prospective TKI through mediation are:

1. Pre-mediation stage

At this stage the mediator will provide advice to the parties in trouble to take the path of peace by way of deliberation, or negotiation or dading. Then the mediator will give a grace period for negotiating so that the parties have the opportunity to go through and provide an explanation to the parties regarding the mediation process. And every decision that is agreed upon and taken by the attorney must obtain written approval from both parties.

2. Mediation Stage

The mediator determines the date for the meeting to complete the mediation process, then the parties come individually or may be accompanied by a legal representative, the mediator will provide suggestions and solutions to explore and explore the interests of the parties so that it can be resolved amicably, the mediation process is carried out a maximum of 40 days work and the results of the agreement are written in the minutes, if no agreement is reached, the mediator suggests taking legal action. If the PPTKIS does not fulfill the call 3 times in a row properly, it will be subject to service delays by BPN2TKI and if during the delay the PPTKIS does not carry out its obligations, it will be subject to sanctions according to applicable regulations and submitted to the Ministry of Manpower.

The mediation registration mechanism is: TKI or families complain to BPN2TKI then received by the crisis center officers are asked to choose mediation or advocacy and submitted to the protection section of BP3TKI, then distributed to the directorate of mediation and advocacy center and regional protection section, then a mediation process is carried out in the form of: parties, clarification, and deliberation if agreed, then completed and signed by both parties, if not then advocacy will be carried out.

Advocacy given to TKI is general and specific advocacy. Advocacy in general is advocacy given to TKI or prospective TKI at the time of placement and provides protection in order to get services and facilities fairly and not discriminated against. While advocacy specifically is advocacy carried out by legal practitioners, generally advocates or lawyers for TKI who experience legal problems, in the form of assistance in the investigation process to the trial process in court in accordance with applicable laws and regulations.

13 Faradina Salima, Roles and Functions of Public Relations Bnp2tki in Building Institutional Image, 2013.p.1. 
The types of legal assistance provided by the government in this case are represented by the National Agency for the Placement and Protection of Indonesian Migrant Workers to prospective Indonesian workers and Indonesian workers who are already working. resolve the problems faced, as well as add insight into laws and regulations relating to employment, law and social affairs, as well as immigration. This BNP2TKI provides information on how to obtain information on existing problem solving procedures, consultation on problems faced by prospective TKKI and TKI related to employment, immigration and legal and social matters,

The coordination mechanism for the handling team of problematic TKI includes the deputy of protection / BP3TKI / LP3TKI / P4TKI / LTSP who obtain information from representatives of the Republic of Indonesia, complaints of Indonesian workers / their families, Non-Governmental Organizations, the media, and several other sources. Then it is coordinated with: BNP2TKI/BP3TKI/LP3TKI, representatives of the placement country in the Republic of Indonesia, the Coordinating Ministry for PMK, the Ministry of Foreign Affairs, the Ministry of Home Affairs, the Ministry of Manpower, the Ministry of Social Affairs/Social Service, the Ministry of Transportation/Transportation Service. Ministry of Health/ Health Service, Ministry of Law and Human Rights/ Regional Immigration, Police, Banking, Manpower Service, Insurance,

The settlement of the case of TKI or prospective TKI is carried out in two ways, namely:

1. Non Litigation

By means of mediation, the process of which is through: calling TKI with problems or their families, PPTKIS, BLK-LN, Insurance, Competency Testing Institutions, which are then expected that TKI can obtain their rights.

2. Litigation

This settlement path is taken if the non-litigation path is not completed, by taking legal or court proceedings, and being processed in accordance with the applicable legal rules.

As citizens who do not work in their country, they must also get legal protection as a guarantee from the state of law against their citizens. ${ }^{14}$ For this reason, the government is responsible for and participates in solving legal problems for Indonesian workers who are abroad as a tribute to their citizenship.

In terms of the pre and during mediation or advocacy processes, BP3TKI is very helpful, especially as an intermediary between BNP2TKI and the CTKI/TKI who report. In addition, at the case reporting stage,

14 Ali Ismail Salih, and Raihana Nasution, Legal Protection of Indonesian Migrant Workers in Saudi Arabia as a Non International Convention On The Protection Of The Rights Of All Migrant Workers And Members Of Their Families, Jurnal Yustisiabel 4.1 2020.hlm.27-39. 


\section{Fatimatul Uluwiyah}

BP3TKI is very helpful to BNP2TKI, especially for the Directorate of Mediation and Advocacy in preparing the reporting documents and also helps provide complete information or information related to the problems submitted by the complainant so as to facilitate the classification of cases when in mediation. ${ }^{15}$

The advocacy stages carried out by BNP2TKI are that the TKI can make a complaint directly to the office or by letter, telephone, email, fax, etc. after that it is received by the crisis center officer to be identified and collaborated with the Directorate of Mediation and Advocacy, and the protection section of BP3TKI to be identified and then the complaint file is distributed. to the central Directorate of Mediation and Advocacy and then to the regional protection section so that the process is recorded in the area of origin of the migrant worker. After that, a mediation process is carried out by calling the relevant parties, conducting clarification, and deliberation if the case does not get an agreement, it is recommended to carry out an advocacy process. ${ }^{16}$

The existence of TKI itself has a great influence on Indonesia, namely being one of the largest foreign exchange earners for the country. According to Bank Indonesia reports from 2010 to 2013, the state received approximately USD 27 million from Indonesian workers working overseas (Bank Indonesia, 2013). The wages received are not only beneficial for migrant workers but the state also benefits. As one of the permanent contributors to the country's foreign exchange earnings, the protection facilities provided to TKI should be given to the maximum or more, but in reality the number of problems faced by TKI from year to year has increased and is quite high. Starting from the problems that befell TKI such as getting rough or inhumane treatment, not being paid, mistreated, sexual harassment, not being sent home or exceeding the contract period, unilateral layoffs and others. This treatment is part of the violation of the rights of migrant workers that occur abroad. ${ }^{17}$

15 Kyla Gloriana Lauditta, Implementation of Perka BNP2TKI Number 28 of 2015 Concerning Problem Resolution Through Mediation and Advocacy, Journal of Politic and Government Studies 8.04 2019, hlm.151-160.

16 Shelly Puspita Sari, Advocacy for the National Agency for Placement and Protection of Indonesian Migrant Workers (Bnp2tki) in Providing Protection for Indonesian Migrant Workers, 2016.

${ }^{17}$ Chandra Kusuma Wijaya, Ika Riswanti Putranti, and Hermini Susiatiningsih. BNP2TKI's Efforts in Overcoming Human Trafficking of Indonesian Migrant Workers in Malaysia 2010-2013, Journal of International Relations 1.1 2017. Pg. 1 8. 


\section{GOVERNMENT RESPONSE IN PROVIDING LEGAL AID FOR MIGRANT WORKERS}

Today, Indonesia is one of the largest international senders of migrant workers, especially manual workers and domestic helpers (PRT), or domestic workers in Asia. This situation is an opportunity for the Indonesian Manpower Service Company (PJTKI), to take advantage of and accommodate the various interests of the workforce. However, the condition of workers from Indonesia is different from the conditions of workers from other countries. Indonesian Migrant Workers (TKI) are often problematic both individually for themselves, and in general for the Indonesian government. Some of the countries that are the destination are Malaysia, Singapore, Hong Kong, Taiwan, and countries in the Middle East (Saudi Arabia). ${ }^{18}$

The loss suffered by the victim will cause psychological burden and pressure, such as feeling annoyed, irritated, prolonged fear, trauma, stress, or even mental disorders. ${ }^{19}$ Based on the cases and the results of monitoring the concept of placement of migrant workers so far implemented by the Government of Indonesia, it has given birth to or raised problems for the families of migrant workers which have an impact on oppression and injustice to migrant workers and their families. ${ }^{20}$

In order to realize the goal of placing and protecting TKI abroad, BNP2TKI was formed as a government agency that implements policies in the field of placement and protection of TKI in a coordinated and integrated manner. BNP2TKI assisted by BP3TKI in the provincial capital and/or the place of departure of the TKI as deemed necessary. ${ }^{21}$ Providing protection to Indonesian workers abroad requires crosssectoral coordination involving the participation of stakeholders both at home and abroad. Without cooperation with related agencies and parties, it is difficult to carry out these main tasks optimally, for domestic purposes, there must be close coordination between the Ministry of Manpower and Transmigration, the Ministry of Foreign Affairs, Regional Government, Immigration, the National Agency for the

18 Henny Nuraeny, Sending Migrant Workers as One Form of Modern Slavery from the Crime of Trafficking in Persons, Journal of Law and Justice 4.3 2015, pp. 501518 .

19 Soedjono Dirdjosisworo, Response to Crime, (Bandung: STHB Press, 2002), p. 5.

20 Andriyeni, Proposals and Recommendations for Women's Solidarity on Revision of Law Number 39 of 2004, (Jakarta: Women's Solidarity, 2004), p. 26.

21 Aris Riyanto Seno Aji, Implementation of Legal Protection for Indonesian Migrant Workers in South Korea by BNP2TKI, (Analysis of Legal Protection for Indonesian Migrant Workers Pre, Period, and Post Placement). (Semarang: UNISSULA Faculty of Law, 2017), p. 33. 


\section{Fatimatul Uluwiyah}

Placement and Protection of Workers in Indonesia. Indonesia (BNP2TKI), law enforcement officers and other technical agencies. For private institutions, it is the Implementing Private TKI Placement (PPTKIS) and its network of recruiters as well as community organizations and non-governmental organizations. ${ }^{22}$

The important role of the government, both central and regional in the protection of migrant workers abroad, is: first, the state is obliged to protect every citizen wherever they are and whatever they do. While the responsibility of the state can be found in the purpose of the state as stated in the fourth paragraph of the opening of the 1945 Constitution, namely not only protecting citizens but also realizing public welfare. ${ }^{23}$ The Indonesian government must protect the human rights of its citizens both at home and abroad.

The enforcement of human rights in its implementation is not only sufficient to include the articles contained in the law on human rights in the constitution as a form of guarantee for the protection of Indonesian migrant workers, but the guarantee must also be contained in the legislation. other. Even instruments in international human rights must also be ratified in an effort to realize law enforcement. ${ }^{24}$ Assistance in the legal field is also very necessary to protect the foreign exchange contributors of this country in order to protect Indonesian citizens who are abroad as stated in the Constitution which reads to protect the entire Indonesian nation and all Indonesian bloodshed. ${ }^{25}$

Legal protection for workers is an important thing carried out by the government. Regional authorities between countries are often the main obstacle in the process of legal protection for workers. ${ }^{26}$ In international law there are provisions that stipulate that a country has the right and responsibility to protect its citizens who are abroad and a country (receiving country) is responsible for violations against foreigners. This concept is known as "Diplomatic Protection" (diplomatic protection). Talking about diplomatic protection, this will be closely related to the role of consular representatives and the demands of a country to other countries related to violations of international law.

22 Adharinalti, Protection of Irregular Indonesian Migrant Workers Abroad, Journal of Rechtsvinding Media for National Law Development, Vol. 1, No. 1, April 2012.p. 162

23 Ida Hanifah, Roles and Responsibilities of the State in Legal Protection of Indonesian Migrant Workers with Problems Abroad, DE LEGA LATA: Journal of Legal Studies 5.1, 2020, pp. 10-23.

24 Muntoha, Unraveling the Complexity of Human Rights (Multi Perspective Studies), (Yogyakarta. Pusham UUI, 2007) page 262

25 Na'im, Mohammad Imamin. "ROLE OF PJTKI IN THE PROTECTION OF INDONESIAN WORKERS." Dynamics: Scientific Journal of Legal Studies 25.1 (2019).

26 S. Djuni Prihatin, A blurry portrait of the protection of Indonesian Migrant Workers (TKI), Journal of Social and Political Sciences 10.3 ,2007. p. 339. 
Diplomatic protection can be carried out by a country (sending country). ${ }^{27}$

In order to deal with the problems faced by Indonesian Migrant Workers, the government has made several efforts, both improvements in the field of legislation, intensive cooperation with countries that will become partners in sending Indonesian Migrant Workers, as well as conducting training and mentoring for Indonesian Migrant Workers. Prospective Migrant Workers before being dispatched abroad. In addition, the government also carries out and forms an organization and bureaucracy, with the existence of the National Agency for the Placement and Protection of Indonesian Migrant Workers and provides social, employment and health insurance for Indonesian workers, both those who are working and those whose work agreements have been completed.

Regarding legal issues and the provision of legal assistance, the Government has provided assistance as stipulated in the Law on the Protection of Indonesian Migrant Workers in several ways, such as through mediation and advocacy, by providing and budgeting the budget to provide legal assistance for Indonesian migrant workers who experience problems. law. However, there are several obstacles in providing legal aid, and shortcomings.

So far, Indonesia is considered to have too many cases of legal problems for Indonesian workers, not commensurate with the existing budget. The government's performance is considered less serious in responding to legal problems faced by Indonesian workers. In fact, when viewed based on the contributions given by Indonesian Workers, Indonesian Workers are contributors to 10 percent of the state budget, so they are called foreign exchange heroes. By paying contributions in the form of a work visa whose contract is limited by time.

The pattern of assistance carried out by NGOs in dealing with TKI problems is to use a "tiered mentoring" pattern, where each case of TKI in a certain village will first be handled by the JKPS NGO at the village level with the aim that it is considered that the NGO representative in the village will know for sure cultural and sociological aspects of the area ${ }^{28}$ Henceforth, if within the village scope it cannot be handled, it will be delegated to the sub-district and so on up to a higher level. So if the village can't handle it and raises its hand, it will be handed over to a higher level and village affairs are considered complete.

27 Pinoke, Edward Richard J, GOVERNMENT RESPONSIBILITY FOR VIOLATIONS OF HUMAN RIGHTS FOR INDONESIAN WORKERS, LEX ET SOCIETATIS 1(5),2013, p. 3. See also Sulistiyono, T., Arifin, R., Wedhatami, B., \& Damayanti, R. (2021). Perlindungan Buruh Migran Indonesia di Korea Selatan di Masa Pandemi Covid-19. Seminar Nasional Hukum Universitas Negeri Semarang, 7(1). https://doi.org/10.15294/snhunnes.v7i1.719

28 Robby Darwis Nasution, JKPS Cahaya NGO Advocacy Model Against Migrant Workers from Ponorogo Regency, Journal of Legal Problems 46.1, 2017, pp..30-48. 


\section{Fatimatul Uluwiyah}

In this case the protection and provision of legal aid cannot only involve one party, but requires cooperation from various parties, Indonesian Workers cannot stand alone and need legal protection and assistance from the government, then the Government cannot know of legal problems without any information and complaints from various parties, in this case the role of NGOs, the mass media is very much needed to change the order of justice for the better.so that a policy is needed for the protection of migrant workers, namely policies that are formulated by involving the roles of the actors involved, namely the government, the private sector, NGOs and migrant workers. ${ }^{29}$ For this reason, it is necessary to have cooperation and synergy in every institution to create justice and prosperity for every citizen of Indonesia.

With the cooperation and coordination of each institution and active participation, it is hoped that justice can be realized for all Indonesian citizens, both at home and abroad, as well as the realization of welfare for all groups in all fields, in this case especially in the economic sector people have the right to a decent life and decent work in accordance with the mandate of the preamble of the 1945 Constitution. BNP2TKI is expected to be able to provide certainty of legal assistance for TKI who are affected by legal problems, and save the rights of Indonesian Migrant Workers who have been violated, as well as create a equality for every human being.Through mediation and advocacy given as much as possible to resolve legal problems that occur to Migrant Workers who in fact are foreign exchange heroes for the Indonesian state.

\section{CONCLUSION}

Indonesian Migrant Workers often have legal problems abroad, in response to this the Government provides legal assistance and protection by conducting job training and selection held by BNP2TKI and completing administrative requirements for prospective Indonesian Migrant Workers, and for Indonesian Migrant Workers The government provides legal assistance in two forms, namely mediation and advocacy as a form of responsibility and protection for citizens, so that justice and prosperity can be created, as well as a sense of security and protect human rights. As a form of the Government's responsibility in providing legal protection for Indonesian Migrant Workers, the Government established the National Agency for the Placement and Protection of Indonesian Migrant Workers, and is active in coordinating between institutions related to the fulfillment and legal protection for Indonesian Migrant Workers, such as NGOs, the public, and the media. mass. As well as

29 Anita Kristina, Competence Standardization as an Effort to Protect Indonesian Migrant Workers, Neo-Bis 6. 2 .2012. pp.102-115 
establishing new regulations that provide more legal certainty for Indonesian Workers who experience problems abroad.

\section{REFERENCES}

Adharinalti, A. (2012). Protection of Irregular Indonesian Migrant Workers Outside State, Journal of Rechtsvinding Media Development of National Law, 1(1).

Aji, A. R. S. (2017). Implementation of Labor Law Protection Indonesia in South Korea By BNP2TKI, (Analysis of Legal Protection of Indonesian Migrant Workers Pre, Period, and Post Placement). Semarang : Faculty of Law UNISSULA.

Andriyeni, A. (2004). Proposals and Recommendations on Women's Solidarity on the Revised Law Number 39 of 2004. Jakarta: Women's Solidarity.

Arpang, A. (2016). Legal Protection Against Indonesian Migrant Workers Outside State, Journal of Legal Reform 3(1), 149-156.

Baswir, R. (2006). People's Economy: People's Economy and Cooperatives as The pillar of the National Economy. Research Institute of Ganesha University of Education. Journal of Social Sciences and Humanities, 2(1).

Concerned, S. D. (2007). A blurry portrait of the protection of Indonesian Migrant Workers (TKI), Journal of Social and Political Science 10(3).

Dirdjosisworo, S. (2002). Response to Crime. Bandung: STHB Press.

Fauziati, A. (2015). Legal Protection for Indonesian Migrant Workers who Death Convicts Abroad in Indonesian Legislation. Collection of Law Faculty Student Journals

Fenny, S. (2014). The role of Indonesian migrant labor unions in protecting rights Indonesian workers abroad, Pandecta: Research Law Journal, 9(2), 257-272.

Government Regulation Number 3 of 2013 concerning Indonesian Labor Protection Overseas

Hanifah, I. (2020). The Role and Responsibilities of the State in Legal Protection Indonesian Migrant Workers with Problems Abroad, DE LEGA LATA: Journal of Legal Studies 5(1), 10-23.

Kristina, A. (2012). Competency Standardization as an Effort to Protect Indonesian Migrant Workers, Neo-Bus 6(2), 102-115.

Lauditta, K. G. (2019). Implementation of Perka BNP2TKI Number 28 of 2015 On Problem Solving Through Mediation and Advocacy, Journal of Politic and Government Studies 8(4), 151-160.

Law Number 16 of 2011 concerning Legal Aid

Law Number 18 of 2017 concerning the Protection of Migrant Workers

Marnesia, T. P. (2019). The Role of the National Agency for Placement and Protection Indonesian Migrant Workers (BNP2TKI) Against 
Fatimatul Uluwiyah

Migrant Workers Who Violate Work Agreement Clauses in Law Number 18 of 2017. Jakarta: Veterans National Development University Jakarta.

Maryono, A. S., et.al. (2012). Critical Study of Law Number 162011 on Legal Aid, National Seminar on Optimizing Legal Aid in Indonesia The Struggle for the Poor. Yogyakarta: Atmajaya University.

Muntoha, M. (2007). Unraveling the Complexity of Human Rights (Multi Perspective Studies). Yogyakarta: Pusham UUI.

Na'im, M. I. (2019). ROLE OF PJTKI IN PROTECTION INDONESIAN MANPOWER. Dynamics: Scientific Journal of Legal Studies 25(1).

Nasution, R. D. (2017). JKPS Cahaya NGO Advocacy Model for Workers Migrants from Ponorogo Regency, Journal of Legal Problems 46(1), 30-48.

Ngazizah, E. R. (2004). Encouraging the Guarantee of the Right to Legal Aid for Migrant Workers in the Revision of Law Number 39 of 2004 concerning the Placement and Protection of Indonesian Migrant Workers Abroad.

Nuraeny, H. (2015). Sending Migrant Workers as One Form Modern Slavery from the Crime of Trafficking in Persons, Journal of Law and Justice 4(3), 501-518.

Pinoke, J., \& Richard, E. (2013). GOVERNMENT RESPONSIBILITY TO VIOLATIONS OF HUMAN RIGHTS FOR INDONESIAN WORKERS, Lex et Societatis 1(5).

Regulation of the Minister of Manpower Number 7 of 2017 concerning the Guarantee Program Indonesian Labor Social

Salih, A. I., \& Nasution, R. (2020). Labor Law Protection Indonesian Migrants in Saudi Arabia as a Non International Convention On The Protection Of The Rights Of All Migrant Workers And Members of Their Families, Jurnal Yustisiabel 4(1), 27-39.

Salima, F. (2013). The Role and Function of Public Relations of BNPTKI in Building Image Institution.

Sari, S. S. (2016). Advocacy of the National Agency for Placement and Protection Indonesian Migrant Workers (BNP2TKI) in Providing Protection to Indonesian Migrant Workers.

Sulistiyono, T., Arifin, R., Wedhatami, B., \& Damayanti, R. (2021). Perlindungan Buruh Migran Indonesia di Korea Selatan di Masa Pandemi Covid-19. Seminar Nasional Hukum Universitas Negeri Semarang, 7(1). https://doi.org/10.15294/snhunnes.v7i1.719

Wijaya, C. K., Putranti, I. R., \& Susiatiningsih, H. (2017). BNP2TKI's Efforts in Overcoming Human Trafficking of Indonesian Migrant Workers in Malaysia 2010-2013, Journal of International Relations 1(1), 1-8. 
When I see the migrant workers broken bodies and eyes without hope, I want to embrace and wipe away their fears. It makes me angry and helps me to keep fighting the oppressive system.

Irene Fernandez 
Fatimatul Uluwiyah

\section{Conflicting Interest Statement}

All authors declared that there is no potential conflict of interest on publishing this article.

\section{Funding}

None

\section{Publishing Ethical and Originality Statement}

All authors declared that this work is original and has never been published in any form and in any media, nor is it under consideration for publication in any journal, and all sources cited in this work refer to the basic standards of scientific citation.

Cite this article as:

Uluwiyah, F. (2021). The Voice of Indonesian Migrant Workers Abroad: How is the Legal Assistance for Them?. The Indonesian Journal of International Clinical Legal Education, 3(3), 257-266. https://doi.org/10.15294/ijicle.v3i3.4826 